\title{
Aneurysmal bone cyst of the sphenoid with orbital involvement
}

Moorfields Eye Hospital, City Road, London, Department of Radiology J V Hunter I F Moseley

Orbital Clinic J E Wright

Correspondence to:

Dr Jill V Hunter, Lysholm Department of Radiology, National Hospital for

Nervous Diseases, Queen Square, London WCIN 3BG.

Accepted for publication 15 February 1990 C Yokoyama

\begin{abstract}
We present a case of aneurysmal bone cyst involving the roof of the orbit and sphenoid bone, with plain film, computed tomography, and magnetic resonance imaging findings. The natural history and treatment depend on the presence of associated abnormalities such as fibrous dysplasia or a giant cell tumour. In this case the lesion was solitary and was successfully removed, so that possible complications from radiotherapy were avoided.
\end{abstract}

Aneurysmal bone cyst (ABC) is uncommon. The commonest site in $40-50 \%$ of cases is the metaphysis of a long bone. In the skull $\mathrm{ABC}$ is rare, representing less than $1 \%$ of cases: of 59 in the literature 15 involved the orbit ${ }^{1-15}$ of which four affected the sphenoid bone ${ }^{181214}$ and one the sphenoid sinus. ${ }^{10}$

There is an association between peripheral $\mathrm{ABC}$ and other bony abnormalities; an associated lesion has implications for the choice of treatment. We describe a boy with a lone $\mathrm{ABC}$
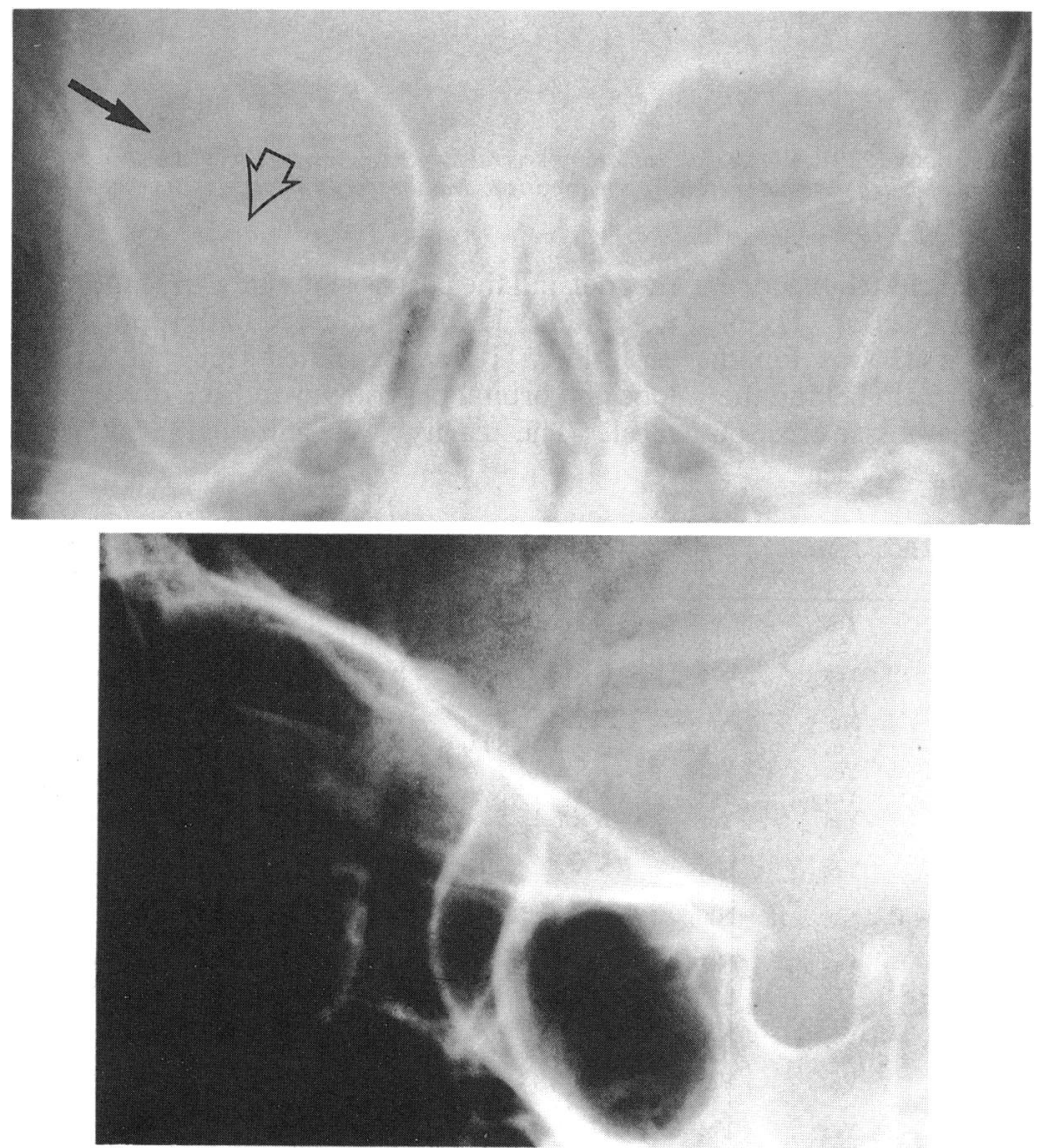

Figure 1: Postero-anterior (upper) and lateral (lower) radiographs at the time of presentation (November 1988). The right orbit is marginally larger than the left, and there is a small area of osteolysis with surrounding sclerosis (solid arrow) in its roof. The sphenoid ridge is slightly less distinct (open arrow) than its fellow. involving the greater and lesser wings of the sphenoid.

\section{Case report}

A 7-year-old white boy presented with a history of one month's variable, painless, periorbital swelling, without visual disturbance. There was no relevant past history, in particular no head injury. There was right sided periorbital swelling, with $4 \mathrm{~mm}$ axial proptosis. Visual acuity was $6 / 9$ in both eyes; examination otherwise gave normal results. Plain skull radiographs showed a small mixed density lesion posteriorly in the roof of the orbit (Fig 1). Six days later there was no palpable mass or sign of inflammation. The right eye still showed $3 \mathrm{~mm}$ axial proptosis, unchanged with head positioning or the valsalva manoeuvre. The physical findings were thought to represent a small orbital haemorrhage.

The findings on examination remained unchanged despite further episodes of intermittent proptosis and lid swelling. Fourteen weeks later, however, the right eye was displaced $6 \mathrm{~mm}$ forwards, with limitation of upgaze; horizontal movement was less affected (Fig. 2). Retinal striae were noted, though the optic disc appeared normal. Visual acuity was now $6 / 12$ in the right eye. There was no afferent pupillary defect.

$X$-ray computed tomography (CT) (Fig. 3) demonstrated a very large destructive lesion in the sphenoid bone with layering of high density material suggestive of a cavity containing blood.

Biopsy was performed via a lateral canthotomy (Mr J E Wright). A bluish-purple mass, displacing the periosteum away from the bone towards the orbit, was incised and a cavity containing old blood was entered. Deep to this lay highly vascular, friable tissue, biopsy revealed multinucleate giant cells and osteoid consistent with $\mathrm{ABC}$.

Magnetic resonance imaging (MRI) (Fig 4) showed a large, rounded, well defined mass apparently extending from the right sphenoid into the orbit. $T_{1}$-weighted (IR $1500 / 500 / 40$ )

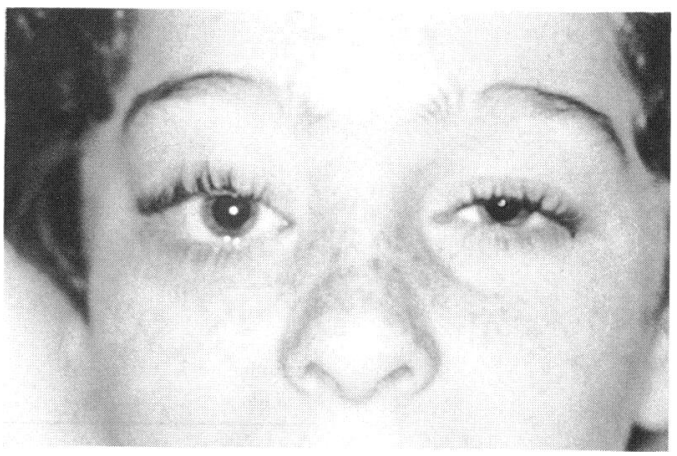

Figure 2: Preoperative appearances with right proptosis. 


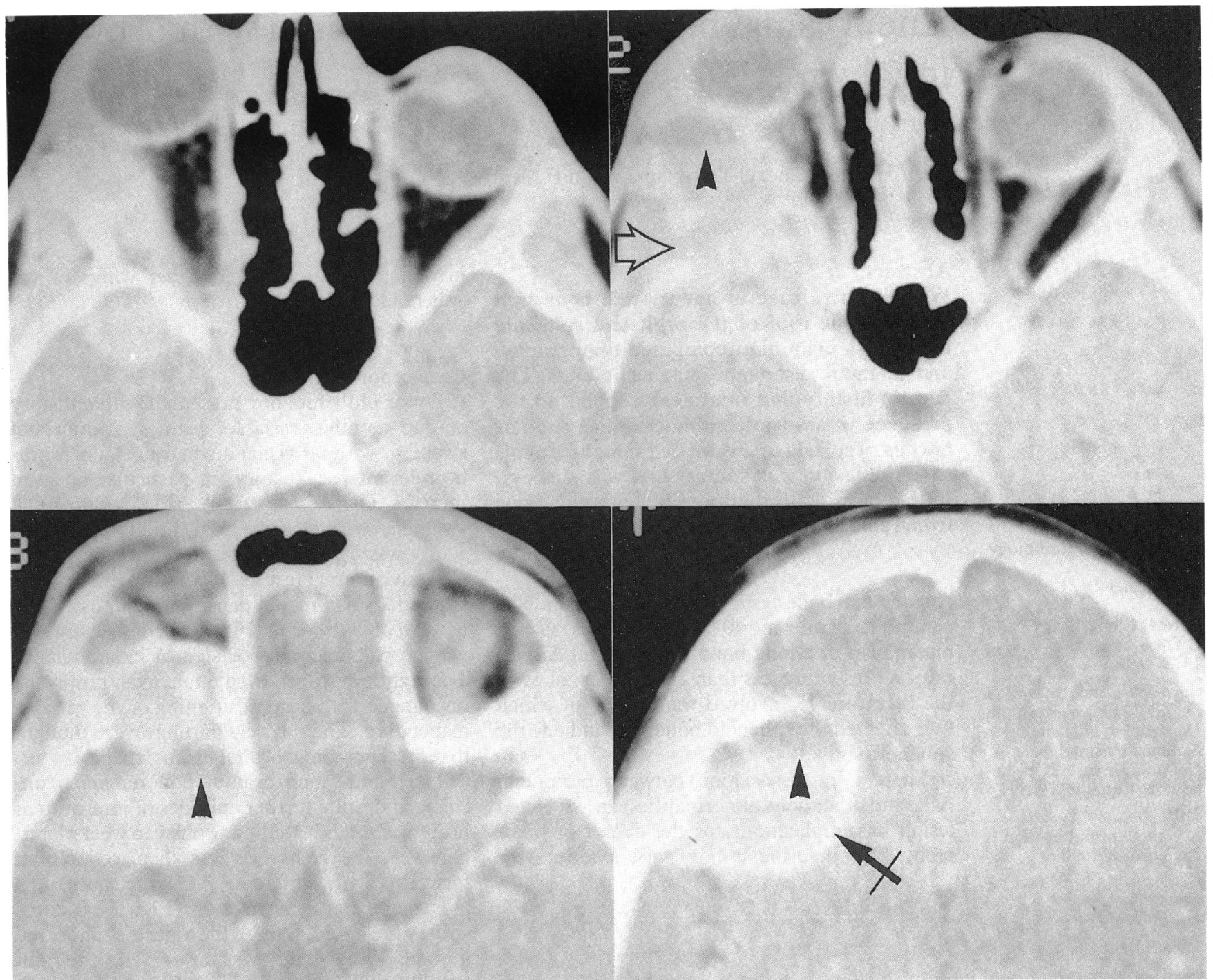

Figure 3: Computed tomography with intravenous contrast medium (February 1989). A large mass containing several fuid levels (arrow heads) due to layering of blood expands into the orbit and the anterior and middle cranial fossae, eroding the bone laterally (open arrow) towards the temporal fossa. It appears to have a capsule (crossed arrow).

images indicated the presence of clotted blood.

At frontal craniotomy (Professor D N

Harrison) a large, vascular, mass was found occupying the orbital roof from $1 \mathrm{~cm}$ behind the orbital rim to the middle cranial fossa. Most of TABLE I Clinical features of orbital $A B C$

\begin{tabular}{|c|c|c|c|c|c|c|c|c|c|c|c|c|}
\hline $\begin{array}{l}\text { Reference } \\
\text { number }\end{array}$ & $\begin{array}{l}\text { Age } \\
\text { (years) }\end{array}$ & Sex & Site & Side & Proptosis & Diplopia & $\begin{array}{l}\text { Visual } \\
\text { acuity }\end{array}$ & $\begin{array}{l}\text { History } \\
\text { (months) }\end{array}$ & Trauma & Pain & Treatment & $F U$ \\
\hline 1 & 22 & M & $\begin{array}{c}\text { Roof } \\
\text { sph. }\end{array}$ & $\mathbf{R}$ & Yes & Yes & Normal & 8 years $^{\star}$ & No & No & Surgery & 2 \\
\hline $\begin{array}{l}2 \\
3 \\
4 \\
5 \\
6 \\
7 \\
8\end{array}$ & $\begin{array}{l}31 \\
8 \\
14 \\
8 \\
10 \\
26 \\
16\end{array}$ & $\begin{array}{l}M \\
M \\
F \\
F \\
F \\
F \\
F\end{array}$ & $\begin{array}{l}\text { Roof } \\
\text { Medial } \\
\text { Roof } \\
\text { Roof } \\
\text { Roof } \\
\text { Medial } \\
\text { Lat } \\
\quad \text { sph. }\end{array}$ & $\begin{array}{l}\mathbf{L} \\
\mathbf{R} \\
\mathbf{L} \\
\mathbf{R} \\
\mathbf{R} \\
\mathbf{R} \\
\mathbf{L}\end{array}$ & $\begin{array}{l}\text { Yes } \\
\text { Yes } \\
\text { No } \\
\text { Yes } \\
\text { Yes } \\
\text { Yes } \\
\text { Yes }\end{array}$ & $\begin{array}{l}\text { No } \\
\text { NA } \\
\text { No } \\
\text { No } \\
\text { Yes } \\
\text { Yes } \\
\text { Yes }\end{array}$ & $\begin{array}{l}\text { Normal } \\
\text { NA } \\
\text { NA } \\
\text { Normal } \\
\text { Normal } \\
\text { NA } \\
\text { Normal }\end{array}$ & $\begin{array}{l}3 \\
2 \\
1 \\
8 \text { Days } \\
3 \\
\text { NA } \\
5\end{array}$ & $\begin{array}{l}\text { No } \\
\text { No } \\
\text { No } \\
\text { No } \\
\text { No } \\
\text { No } \\
\text { No }\end{array}$ & $\begin{array}{l}\text { No } \\
\text { No } \\
\text { HA } \\
\text { No } \\
\text { No } \\
\text { No } \\
\text { No }\end{array}$ & $\begin{array}{l}\text { Surgery } \\
\text { Surgery } \\
\text { Surgery } \\
\text { Surgery } \\
\text { Surgery } \\
\text { Surgery } \\
\text { Surgery }\end{array}$ & $\begin{array}{l}\text { NA } \\
0 \cdot 5 \\
5 \\
0 \cdot 5 \\
\text { NA } \\
\text { NA } \\
3\end{array}$ \\
\hline 9 & $1 \cdot 2$ & $\mathbf{M}$ & Roof & $\mathbf{L}$ & Yes & NA & NA & $<1$ & No & No & $\underset{\times 2}{\text { Surgery }}$ & NA \\
\hline 10 & 10 & $M$ & $\begin{array}{l}\text { Sph. } \\
\text { Sinus }\end{array}$ & $\mathbf{L}+\mathbf{R}$ & No & No & Reduced & Recent & No & No & $\underset{\times 2}{\text { Surgery }}$ & 6 \\
\hline $\begin{array}{l}11 \\
12\end{array}$ & $\begin{array}{l}11 \\
1 \cdot 3\end{array}$ & $\begin{array}{l}\mathrm{F} \\
\mathrm{M}\end{array}$ & $\begin{array}{l}\text { Roof } \\
\text { Roof } \\
\text { sph. }\end{array}$ & $\begin{array}{l}\mathbf{L} \\
\mathbf{L}\end{array}$ & $\begin{array}{l}\text { Yes } \\
\text { Yes }\end{array}$ & $\begin{array}{l}\text { NA } \\
\text { ?Yes }\end{array}$ & $\begin{array}{l}\text { NA } \\
\text { Normal }\end{array}$ & $\begin{array}{l}6 \\
3\end{array}$ & $\begin{array}{l}\text { No } \\
\text { No }\end{array}$ & $\begin{array}{l}\text { No } \\
\text { No }\end{array}$ & $\begin{array}{l}\text { RT + surgery } \\
\text { RT + surgery } \\
\times 2\end{array}$ & $\begin{array}{l}0 \cdot 75 \\
12\end{array}$ \\
\hline 13 & 12 & $\mathbf{F}$ & Roof & $\mathbf{R}$ & Yes & No & Reduced & 10 Days & No & No & $\underset{\times 3}{\text { Surgery }}$ & 3 \\
\hline 14 & 19 & $\mathbf{F}$ & $\begin{array}{l}\text { Lat. } \\
\text { sph. }\end{array}$ & $\mathbf{L}$ & Yes & Yes & Normal & NA & No & Yes & Surgery & $1 \cdot 5$ \\
\hline $\begin{array}{l}15 \\
\text { Hunter } \\
\text { et al }\end{array}$ & $\begin{array}{l}42 \\
7\end{array}$ & $\begin{array}{l}\mathrm{F} \\
\mathrm{M}\end{array}$ & $\begin{array}{l}\text { Roof } \\
\text { Roof } \\
\text { sph. }\end{array}$ & $\begin{array}{l}\mathbf{L} \\
\mathbf{R}\end{array}$ & $\begin{array}{l}\text { Yes } \\
\text { Yes }\end{array}$ & $\begin{array}{l}\text { Yes } \\
\text { No }\end{array}$ & $\begin{array}{l}\text { Normal } \\
\text { Reduced }\end{array}$ & $\begin{array}{l}2 \\
2 \text { weeks }\end{array}$ & $\begin{array}{l}\text { No } \\
\text { No }\end{array}$ & $\begin{array}{l}\text { Yes } \\
\text { No }\end{array}$ & $\begin{array}{l}\text { Surgery } \\
\text { Surgery }\end{array}$ & $\begin{array}{l}1.5 \\
0.75\end{array}$ \\
\hline
\end{tabular}

$M=$ male. $F=$ female. $L=$ left. $R=$ right. sph. =sphenoid. lat.=lateral. $N A=$ not available. $R T=$ radiotherapy. $H A=$ headache. $F U=$ follow-up. ${ }^{\star}$ Rapid progression over one year. 


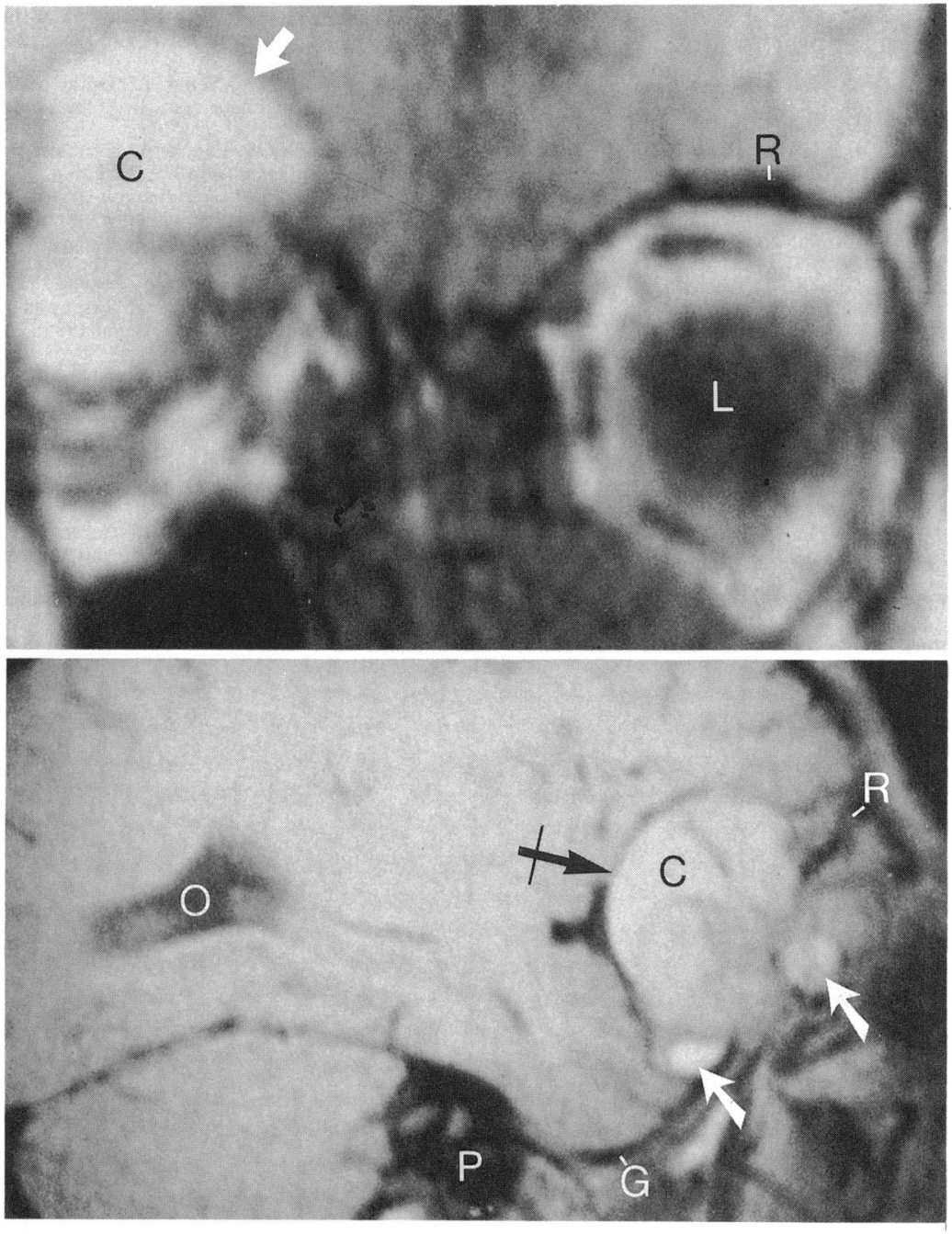

Figure 4: $T_{I}$-weighted coronal (upper) and sagittal (lower) MRI show high signal from the blood filled cavities (white arrows). The central part of the lesion, presumably solid tumour, gives a lower signal on the sagittal image. The cyst $(C)$ is extradural and has a well defined margin (crossed arrow). $C=$ cyst. $G=$ greater wing of sphenoid. $L=$ left globe. $O=$ occipital hor of lateral ventricle. $P=$ petrous bone. $R=$ orbital roof.

ethmoidectomy performed. No transfusion was required. One year later the patient has full extraocular movements and $6 / 6$ vision.

The tumour was composed of spindle cells with large blood-containing cysts, numerous osteoclast giant cells, and reactive bone, confirming the diagnosis of $\mathrm{ABC}$ (Bone Tumour Panel, Royal National Orthopaedic Hospital Stanmore).

TABLE II Radiological features of orbital ABC

\begin{tabular}{|c|c|c|c|c|c|c|}
\hline $\begin{array}{l}\text { Reference } \\
\text { number }\end{array}$ & $\begin{array}{l}\text { Plain } \\
\text { films }\end{array}$ & $N M$ & $\begin{array}{l}\text { Angio- } \\
\text { gram }\end{array}$ & $\begin{array}{l}C T \text { (bone } \\
\text { destruction) }\end{array}$ & Enhancement & $M R I$ \\
\hline $\begin{array}{l}1 \\
2 \\
3 \\
4 \\
5 \\
6 \\
7 \\
8 \\
9 \\
10 \\
11 \\
12 \\
13 \\
14 \\
15 \\
\text { Hunter } \\
\text { et al }\end{array}$ & $\begin{array}{l}+v e \\
+v e \\
+v e \\
+v e \\
-v e \\
+v e \\
+v e \\
+v e \\
+v e \\
+v e \\
+v e \\
+v e \\
+v e \\
-v e \\
+v e \\
+v e\end{array}$ & $+v e$ & $\begin{array}{l}M \\
M \\
M \\
M \text { and } B \\
M \\
M \text { and } B \\
M \text { and } B \\
M \\
M \\
M\end{array}$ & $\begin{array}{l}+v e \\
+v e \\
+v e\end{array}$ & $\begin{array}{l}+v e \\
+v e\end{array}$ & $+v e$ \\
\hline
\end{tabular}

$M=$ mass. $B=$ blush. $N M=$ nuclear medicine.

\section{Discussion}

Aneurysmal bone cyst ${ }^{16}$ is a benign, multicystic, vascular lesion of young people. Up to $85 \%$ of cases occur before 20 years of age, ${ }^{17}$ with one documented case in a 72-year-old. ${ }^{18}$ There is a slight female preponderance. ${ }^{17}$ Half of ABCs involve the metaphyses of long bones and onefifth the spine. The skull and orbit are affected in about $1 \%$; of 59 cases reported in the skull 15 involved the orbit.

Other bony lesions are present in up to onethird of cases. In 57 extracranial ABCs the most common associated lesions were: solitary bone cyst (18), osteoclastoma (14), and osteosarcoma (12). ${ }^{18}$ Other associations include fibrous dysplasia, non-ossifying fibroma, chondroblastoma, fibromyxoma, and giant cell reparative granuloma. ${ }^{19}$ At presentation $\mathrm{ABC}$ may be large, with a history of insidious onset of pain (in more than half) and swelling (in onequarter). Pathological fracture may occur in the long bones or spine. Symptoms have typically been present for less than three months, though $6 \%$ of patients do not present for one year or more. ${ }^{19}$ The recurrence rate for extracranial $\mathrm{ABCs}$ is $21-44 \%$, higher rates occur with incomplete excision and in children. ${ }^{17}$

In the orbit $A B C$ has been reported in nine females and six males aged from 14 months to 42 years. One case had bilateral orbital involvement from a sphenoid sinus ABC. Presenting symptoms included painless proptosis, diplopia, ptosis, headache, visual deterioration, and nasal congestion. The average duration of symptoms was two months (Table I and Table II).

Aneurysmal bone cyst may arise in the roof and/or walls of the orbit. One proposed cause is trauma, but in none of the orbital tumours was injury noted.

Sudden proptosis secondary to rapid expansion of the lesion - presumably haemorrhagic - is common. The rapidity of progression between the slightly abnormal plain film and the grossly pathological CT only 14 weeks later was striking and raised the possibility or malignancy, as in other cases. ${ }^{13}$ However, Dabska and Buraczewski ${ }^{20}$ described four radiological phases: osteolysis; rapid growth; stabilisation; and healing, with progressive ossification. The short history suggests that many patients present during the phase of rapid growth. As in our case, signs of globe compression such as retinal striae may be seen.

None of the reported orbital cases was secondary to another lesion. In keeping with the benign nature of $A B C s$, all remained extradural.

Accepted methods of treating peripheral ABCs include excision, curettage (sometimes with bone grafting), cryotherapy, and radiotherapy. Some of these are not applicable to the orbit. Review of the literature reveals two cases of orbital recurrence, following needling and partial excision, within two years. Two patients received radiotherapy after surgery. ${ }^{112}$ One orbital $\mathrm{ABC}$, mistaken for a giant cell tumour and treated with high-dose radiation, presented again as a heavily calcified mass. ${ }^{12}$ No cases of osteogenic sarcoma complicating radiotherapy have been reported in the orbit, though this has occurred with extracranial ABCs. ${ }^{20}$ Our patient remains well one year after operation. 


\section{CONCLUSION}

Orbital aneurysmal bone cysts appear to form a well defined subgroup of $A B C$ of the skull. Although rare, these potentially curable, benign lesions should be considered in young patients with painless proptosis of rapid onset.

1 Siedenbiedel H. Brauner tumor der orbita. Klin Monatsb Augenheilkd 1953; 122: 86-90.

2 Arnould G, Lepoire J, Tridon P, Schmitt J, Guerci O. Exophtalmie unilaterale par kyste solitaire de l'orbite. Rev Oxophtalmie unilaterale par kyste

3 Kubicz S, Sobieszcanska-Radoszewska L. Przypadek tetniakowatej torbieli kostnej kosci sitowej i czolowej chlopca 8 - letniego. Otolarymgol Pol 1962; 16: 665-9.

4 Costantini FE, Iraci G, Benedetti A, Melanotte PL. Aneurysmal bone cyst an intracranial space-occupying lesion: case report. $\mathcal{F}$ Neurosurg 1966; 25: 205-7.

5 Fite JD, Schwartz JE, Calhoun FP. Aneurysmal bone cyst of the orbit. Ophthalmology 1968; 72: 614-8

6 Offret G, Clay C, Lecoq P-J, Arrata M. Kyste aneurysmal des s à localisation orbitaire. Bull Soc Ophtalmol Fr 1971; 71 : $1049-54$.

7 Komorn RM. Management of vascular tumors of the head and neck. South Med F 1972; 65: 1106-12.

8 Powell JQ, Glaser JS. Aneurysmal bone cyst of the orbit. Arch Ophthalmol 1975; 93: 340-2.
9 O'Gorman AM, Kirkham TH. Aneurysmal bone cyst of the orbit with unusual angiographic features. $A \mathcal{F} R$ 1976; 126 $896-9$.

10 Yee RD, Cogan DC, Thorp TR, Schut L. Optic nerve compression due to aneurysmal bone cyst. Arch Ophthalmo 1977; 954: 2176-9.

11 Flament J, Forest P, Boukoffa OS, Lankar A. Kyste osseux aneurismal de l'orbite. F Fr Ophtalmol 1979; 22: 131-4.

12 Iraci G, Giordano R, Fiore D, Pizzi G, Tomazzoli-Gerosa L, Gerosa $M$. Exophthalmos from aneurysmal bone cyst of the orbital roof. Childs Nerv Syst 1980; 6: 206-17.

13 Ronner HJ, Jones IS. Aneurysmal bone cyst of the orbit: a review. Ann Ophthalmol 1983; 15: 626-9.

14 Calliauw L, Roels H, Caemaert J. Aneurysmal bone cysts in the cranial vault and base of skull. Surg Neurol 1985; 23: the cran

15 Johnson TE, Bergin DJ, McCord CD. Aneurysmal bone cyst of the orbit. Ophthalmology 1988; 95: 86-9.

16 Jaffe HL, Lichtenstein L. Solitary unicameral bone cyst with emphasis on the roentgen picture, the pathologic appearance, and the pathogenesis. Arch Surg 1942; 44: 1004-25.

17 Ruiter DJ, van Rijssel TG, van der Velde EA. Aneurysma bone cysts. Cancer 1977; 39: 2231-9.

18 Levy WM, Miller AS, Bonakdarpour A, Aegerter E. Aneurysmal bone cyst secondary to other osseous lesions. Am f Clin Pathol 1975; 63: 1-8.

19 Biesecker JL, Marcove RC, Huvos AG, Mike V. Aneurysma bone cysts. Cancer 1970; 26: 615-25.

20 Dabska M, Buraczewski J. Aneurysmal bone cyst. Cancer 1969; 23: 371-89. 